\title{
Shakespeare's Influence on Pre-Independence Assamese Tragedy: a Historical Perspective
}

\author{
Mohammad Rezaul Karim ${ }^{1}$ \& Soleman Ali Mondal ${ }^{2}$ \\ ${ }^{1}$ Assistant Professor of English, College of Business Administration Prince Sattam bin \\ Abdulaziz University, Al Kharj, Kingdom of Saudi Arabia. ORCID: 0ooo-0oo2-8178-826o. \\ Email: karimrezaul318@gmail.com \\ ${ }^{2}$ Associate Professor, Department of English, B.N. College, Dhubri, Assam, India \\ ORCID ID: oooo-ooo1-5576-1139. Email:drsolemanmondal@gmail.com
}

\begin{abstract}
In Assamese, the tradition of writing and production of plays on the model of Sankardeva, Madhavdeva and their contemporaries fell into decadence with the arrival of a new type of plays under the influence of Shakespearean dramas. The presence of Shakespeare is deeply felt as close translations of his texts are being done and his style and technique being freely adopted. Some of these Assamese plays have nothing authentically Shakespearean about them but they could not have been written in the first place but for Shakespeare's influence on their writers. Shakespeare is thus the main creative force behind this entire body of dramatic literature in Assamese. Since the late $19^{\text {th }}$ century productions of Shakespearean plays by different writers and his influence on Assamese drama has continued unabated even to this day. In this article, an attempt has been made to selectively focus on pre-Independence Assamese tragedy. It discusses how Assamese drama in general and tragedy in particular, has developed in the light of Shakespeare's tragic vision.
\end{abstract}

Keywords: Shakespeare, Assamese drama, tragedy, translation, adaptation

\section{Introduction}

The greatest English dramatist and poet, William Shakespeare is considered as the magnificent of all the playwrights of the world. His plays converse a far-reaching knowledge of the wellsprings of human behavior, exhibited by way of drawing a broad diversity of characters. Shakespeare's handling of poetic and dramatic methods to produce an amalgamated artistic effect out of an abundance of oral expressions and actions is acknowledged as a peculiar accomplishment, and his treatment of poetry in his dramas to convey the profound volume of human inspiration in individual, social, and universal conditions is regarded one of the greatest achievements in literary history. Ben Jonson, his great contemporary, was right when he called him, "the soul of the age", and also that "he was not of an age, but for all times". His name has become synonymous with two words 'great literature'. According to Maynard Mack, "Shakespeare is the only writer in world literature who actually comes close to belonging to the world" (Mack, 1994, p. 1). There are numerous works on Shakespeare that have established the great author's wide-ranging influence by way of transformation, translation, circulation, and production of his plays in many Indian languages including Assamese. "The Shakespearean presence in India is older and more complex than in any other country outside the West. That is due primarily to India's long colonial past, and the presence of unusually receptive elements in the native culture" (Shakespeare in India).

(C) AesthetixMS 2020. This Open Access article is published under a Creative Commons Attribution Non-Commercial 4.0 International License (http://creativecommons.org/licenses/by-nc/4.0/), which permits non-commercial re-use, distribution, and reproduction in any medium, provided the original work is properly cited. For citation use the DOI. For commercial re-use, please contact editor@rupkatha.com. 
English education introduced by the British provided the basis for the pristine literature that originated first in Bengal and then in other parts of India. The process was hastened by the zeal of the missionaries and the first Bengali periodical Dig-darshan which started appearing in 1818. All these factors combined to open the flood-gates of western ideas which gradually started flowing in different directions throughout the country. Anyone attempting to study western influence in general, and Shakespearean influence in particular, on the Assamese mind, cannot fail to notice the significance of this phenomenon in Bengal inasmuch as in many cases it was through Bengal that the new ideas started filtering into Assam. In fact, the process of transformation was more or less the same everywhere in India; but this is more so of Assam, Bihar, and Orissa because of historical, geographical and political factors (Mahanta, 1985, p. 4). Thus, the nineteenth-century that brought about a renaissance in Bengal also revolutionized the life of the Assamese people in myriad spheres, and the changes soon started reflecting in works of literature.

It was during this period that the writing of dramas on the Shakespearean model was cultivated. "A number of young people from Assam who were receiving higher education in Calcutta not only read Shakespeare but also saw performances of his plays, both in original English and Bengali translation" (Mahanta, 1985, p. 6). The various ongoing reform movements in Bengal at the time also made these young men and women conscious of their backwardness and the various evils that beset their society back in Assam. One of them was Gunabhiram Barua, who wrote and published Ram-Navami Natak in 1857. He was soon followed by Hemchandra Barua (Kaniyar Kirtan, 1861) and Rudraram Bardalai (Bangal Bangalani, 1871), and this trio thus emerged as the pioneers of the new drama in Assamese. Biswadip Gogoi adds, "Hemchandra-Gunabhiram era laid a platform for a new generation of writers to come out and contribute towards the development of Assamese language and literature" (Gogoi, 2017, p. 292). The subject matter of all these plays was social and realistic, while the style and technique were largely modeled on western dramaturgy with echoes of Shakespeare.

Ajitkumar Ghose says, "The greatest contribution of Shakespeare to Bengali literature is tragedy" (1966, pp. 34-35). This is true of Assamese literature as well. "No history-based study of modern Assamese drama is possible without reference to Shakespeare", says Dr. Jyotirmay Jana (Jana, 2015, p. 10). Jogen Chetia opines: "The influence of Shakespeare's drama on modern Assamese drama especially when it was at its formative stage - is immense and long-lasting. The works of no other foreign playwright have been translated or approximated as much as Shakespeare's have been" (Chetia, 1979, p. 31). In this regard, Mahanta (1985) observes:

The nineteenth-century was a period of transition when values were fast changing under the impact of the West, and when the nation was pining for liberty and self-government. In the circumstances, it was natural for the people to suffer from an intense mental conflict, while writers with a deep vision of life found in it material enough for tragic dramas (p. 65).

Shakespearean tragedy springs from man and his interplay with fellow men. Carlton observes, "Shakespeare's concern is with that wonderful piece of work, man and his personality (Carlton, 2011, p. 11). Bradley adds: "the center of the tragedy in Shakespeare may be said with equal truth to lie in action issuing from character, or in character issuing in action" (1991, p. 7). The first tragedy in Assamese, Ram Navami, published in installments in 1857 , is also of similar orientation. There is no trace of a supernatural agency in it, and the tragedy results from the actions of the main characters, who suffer because they rebel against established conventions. This is undoubtedly a remarkable break with the age-old dramatic tradition. Mahanta elaborates, "In fact, it can be said that the secularization of Assamese drama began with Ram Navami under the impact of the 
Elizabethan dramatists, particularly Shakespeare, no matter whether the impact came directly from the original or partly through Bengali" (Mahanta, 1985, p. 66). Gunabhiram Barua not only possesses the deep tragic vision of Shakespeare, but he is also influenced by his themes and techniques and this is evident to anybody familiar with Shakespearean plays, particularly Romeo and Juliet. The tragic became a recurrent theme in the Assamese drama over time with Padmanath Gohain Barua, Lakshminath Bezbaroa, Nakulchandra Bhuyan and other writers who tried their hand at it with varying degrees of success.

An important feature of the Shakespearean tragedy is that it is, to quote A.C. Bradley again, "concerned always with leaders of 'high degree' often with kings or princes; if not with leaders in the state like Coriolanus, Brutus, Antony, at the least, as in Romeo and Juliet, with members of great houses, whose quarrels are of public moment" (Bradely, 1991, p. 4). It is true that the first Assamese tragedy, Ram Navami, is not of this kind as both its hero and heroine, Ram and Navami, came of ordinary families with common human aspirations as well as weaknesses. It, however, is not difficult to find similarities between these two and Romeo and Juliet. Tragedy featuring persons of 'high degree,' or in Aristotelian terms, 'persons better than average man,' was soon to follow. The first of its kind was Padmanath Gohain Barua's Jaymati in which the heroine is one of the most illustrious princesses in the history of Assam. Other tragedies of this kind are Gohain Barua's Sadhani, Bezbaroa's Jaymati, Belimar, and Nakul Bhuyan's Badan Barphkan, and it can be seen that Shakespeare's influence is found in all these plays.

\section{Methodology}

Throughout the article, mainly the comparative method of investigation has been followed on the basis of both primary and secondary sources. Technical devices of both Shakespeare and modern Assamese dramatists have also been studied in detail. Appropriate attention has been paid to the stories and incidents of the Assamese plays discussed in the paper. In most cases, the statements and findings of some renowned scholars have been cited to justify the arguments and to make the study logical and reasonable.

\section{Salient features of old Assamese drama prior to Shakespearean influence}

Although the history of Assamese literature started with the Charyapadas (Buddhist songs, assumed to have been written within the time of four hundred years, starting from $8^{\text {th }}$ century A.D. to $12^{\text {th }}$ century A.D.), the regular history of Assamese Literature began when Sakardeva, the great saint-poet, artist-philosopher, social reformer and preacher of the neo-Vaishnavite order, started writing in various genres. His chief apostle, Madhavadeva composed and produced plays on the lines of his great master. According to Satyendranath Sarma (1964),

Some writers also wrote a few plays in Sanskrit, interspersed with Assamese, during the seventeenth and the eighteenth centuries, but these plays had no popular appeals as they were unintelligible to the masses, and so failed to leave any mark on the development of Assamese drama (p. 103).

By the old Assamese dramas, we generally mean the plays of Sankardeva and his followers which are popularly known as the Ankiya nats. The dominant feature of these plays is an unmistakable note of religion in them. The Ankiya nats were written more with a religious motive than for secular enjoyment. The aim of the playwright was to teach the audience the tenets of Vaisnavism by staging before them the exploits of the Vaisnavaite gods Krishna and Rama. The other 
noteworthy characteristic feature of Ankiya nat is its essential lyrical nature. Birinchi Kumar Barua (2015) observes:

In these plays songs and verses greatly preponderate and the playwrights largely use them to bring home the message inculcated in the play. Many situations and incidents are suggested by mere descriptive verses instead of being represented through character and action (p. 34).

Another important characteristic of this drama is the preponderance of the Sutradhara. Unlike in a Sanskrit play, says Banikanta Kakati (2007),

the Sutradhara in an Assamese drama remains on the stage all through the performance. He sings the 'Bhatima' or introductory verses, explains the subject-matter of the play, and announces the entrance and exit of the chief characters. He also gives stage-directions, suggests incidents and situations which cannot be shown on the stage, and sings the benedictory verses known as the 'mukti-mangal bhatima.' Thus, the Sutradhara is a central figure in an Assamese play (p.114).

Apart from Sutradhara, there used to be two other characters in an Assamese play, that are known as the Duta and Bahuva. However, they are not in the class of the dramatic personae, and they are found in actual performances of the play to perform as preludes and to provide comic relief. The language used in these plays has another striking feature. This is known as Brajawali bhasa, which is largely made up of Maithili and Assamese. Brajawali or Brajabuli, as it is called in Bengal, was not a spoken language of any particular region. It was an artificial dialect created by the medieval Vaishnavite poets in which the Krishna stories were written. Sukumar Sen (1955) opines,

This artificial language was given the name of Brajabuli because it reminded one of the Braja, the land sanctified by the presence of Radha and Krishna. The term, Brajabuli, however, should not be confused with the name of the actual spoken language, a form of Western Hindi of the district round about Muttra (p. 3).

The same can be said about Assamese Brajabuli also. Satyendranath Sarma (1973) adds,

Sankaradeva and his followers used this language because this would be intelligible not only to the common people of Assam but to those of the whole of Eastern India. It was well-suited to glorify the activities of Krishna before the common folk. While Sanskrit would be Greek to them if it were adopted, ordinary day to day Assamese would be too mundane for the purpose (p.18).

The most important aspect of the performing of an Ankiya nat is the synchronization and consonance of the four elements - song, rhythmic delineation by dance, melody emerging from pertinent musical apparatus, and dialogue. The entire account of the story advances through dances, and dancing is contemplated as one of the best arts for arousing feeling. Thus, according to Birinchi Kumar Barua (2015),

This new genre of literature, combining different forms of art and giving them a composite expression of its own, happens to be the most remarkable phenomenon in the history of Assamese literature. Although an ethico-religious mood is the dominant note of the Ankiya nats, they have admirably dovetailed the dance-tradition of the soil into the classical tradition of drama and music along with occasional gleanings of art-fragments from different parts of India (p. 41). 
5 | Shakespeare's Influence on Pre-Independence Assamese Tragedy: a Historical Perspective

\section{Shakespeare and Assamese Tragedians}

Gunabhiram Barua (1834-1894) is intimately associated with the growth of modern secular drama in Assamese. He was one of the first young men from Assam to go to Calcutta for college education. He studied at Presidency College for two years but had to discontinue his studies and join Government service. During his stay in Calcutta as a student, he came in close contact with the new ideas that marked the Indian renaissance. Attracted by the liberal ideas of the Brahmo Samaj, he converted to Brahmaoism and wished that Assam would prosper by accepting this faith, which was in some sense already propagated by Sankardeva and Madhavadeva centuries ago. He was greatly influenced by Ishwar Chandra Vidyasagar, and he not only advocated widow remarriage but married a widow himself. He wrote Ram Navami in 1857 when he was on his way back home from Calcutta. The same year it was serialized in Arunodoi, although it did not come out in book form until 1870 . Misra specially underscores the social relevance and psychological depth of this play in the following words: "Gunabhiram Barua's Ramnabami Natak, arguably, a lone voice rooting for widow remarriage in the still conservative Assamese milieu struck a note of transgression with his bold and often bluntly prescriptive sexual ideals flaunted by the two lovers, Ram and Navami, caught tragically in the warp of time" (Misra, 2007). The title of Ram Navami is based on the names of the hero and heroine Ram and Navami. It reminds us of Shakespeare's Romeo and Juliet a drama deriving its title from its chief protagonists' names. Both the plays are tragedies and the heroes and heroines meet catastrophe. Shakespeare wrote Romeo and Juliet at an early age, and Gunabhiram too wrote Ram Navami when he was only 20 years of age. The notion of tragedy is not known to the tradition of Ankiya Nat. It is Gunabhiram Barua, who for the first time set through Ram Navami, a firm notion of tragedy of Shakespearean orientation in the archive of Assamese drama. Thus, Ram Navami is the first non-religious play in Assamese literature from different perceptions. This was composed at a time when no one could conceive the concept of secularism on account of the existing traditions of Ankiya Nat. But, it was done by Gunabhiram Barua only because of the intense influence of Shakespeare.

Benudhar Rajkhowa's Seuti-Kiran was first published in 1894. Commenting on Shakespeare's influence on it, in terms of theme and treatment, Mahanta states, "It showed that western influences had been actually working in insensible ways, for we find in this play, besides the general dramatic pattern, a marked influence of Shakespeare, both in theme and its treatment" (Mahanta, 1985, p. 193). Rajkhowa was a student at Ripon College in Calcutta where Surendranath Banerjee taught English literature. It was but natural that he developed a great love for English literature, particularly Shakespeare, whose influence on him is faithfully reflected in Seuti-Kiran which he wrote when he was still a student at college. Hazarika (1967) gives some enlightening personal details of Rajkhowa's life:

Benudhar was himself an actor and associated with literary and dramatic activities whenever he was posted during his tenure of government service. Once he played the role of the Duke in Bhramaranga (The Comedy of Errors) performed by the A.S.L. Club at Calcutta and later he took part in different dramatic performances organized by various theatres in Assam (p. 103).

It shows that Rajkhowa knew how to make a play appealing to the popular taste. The introduction of elements such as ghost, murder, and suicide might be due, besides Shakespearean influence, to the fact that such external incidents, as pointed out earlier, had great appeal to the audience of the time. Dayananda Pathak observes in this regard, "Seuti Kiran bears many similarities with Shakespeare's Hamlet and Othello" (Pathak, 2008, p. 54). As a play Seuti-Kiran has drawbacks, but to discuss them would not be germane to the present purpose. Seuti-Kiran is a seminal play, for it 
points to an important factor in the making of modern Assamese drama. While the playwrights of the latter part of the nineteenth-century had certainly learned to deal with social themes, a proper dramatic form was still not developed for that purpose.

An adaptation of Romeo and Juliet by Padmadhar Chaliha appeared in 1919. A Master of Arts in English Literature from Calcutta University, playwright and actor, Chaliha was a great admirer of Shakespearean drama. He was instrumental in introducing Shakespeare to the Assamese audience through this romantic tragedy Amar-Lila noted for its lyrical beauty and passionate love. He was aware of the limitations of such a work, and therefore he admits: "It is near impossible to translate the play keeping the beauty of the original intact. Yet, considering that such deep thoughts and touching feelings should be part of our own literature, I have endeavoured to write this piece in imitation of Shakespeare's play" (Chaliha, 1946). In this play, Amar (Amarsimha) and Lila (Lilavati) stand for Romeo and Juliet respectively. The story is Indianised and recast against Rajput background with Rajput names for the major characters, although the minor ones sound very much Assamese. The scene of the story is Udaypur, a Rajput kingdom, and instead of the age-old enmity between the two families in the original play, two Rajput clans are presented to be at variance with each other. Bhimsimha and Govindasimha, standing for Montague and Capulet respectively, are represented as military chiefs belonging to the two feuding clans.

In 1932, Nabinchandra Bardalai translated King Lear which he named Vishad Kahini, meaning a story of sorrow and grief. The play, as available now, is incomplete and we do not know if Bardalai translated the whole play or left it unfinished. The second possibility seems to be stronger as Vishad Kahini was written when the author was in prison. It may very well be that Bardalai was released when he was halfway through the translation, and the work was abandoned as he immersed himself in the freedom struggle again. Be that as it may, the play as we have it now, is fragmentary; the style, too, is somewhat coarse and lacking in refinement. The story takes place against Indianised background at an indeterminate point of time in history. The names sound Rajput but the term 'simha' is tagged to most of the male characters. The translation is so laboriously literal that even Shakespearean structures and turns of phrase are brought over into Assamese. In fact, as a translation, Vishad Kahini is far from agreeable. It might have been written in haste in jail, of which there are many traces; but that is hardly an excuse for its being of poor quality. Therefore, except as a work of some historical significance, Vishad Kahini seems to count for very little as a Shakespearean play in Assamese (Mahanta, 1985).

Ambikaprasad Goswami's Tara, an adaptation of Cymbeline, appeared in print in 1935, but it was performed as early as in 1915 by the Kamrup Natya Samity. The story is adapted to an Indianised setting with the Rajputs and the Mughals standing for the British and the Romans, respectively. Cymbeline, king of Britain, becomes Ajitsimha, king of Jaypur, Casius Lucius, general of Roman forces, becomes Ramsimha, general of the Mughal forces attacking the Rajput kingdom. Belarius, the banished lord, is presented as Vikramsimha, a banished general disguised as a Bhil with Guiderius and Arviragus as two Bhil youths, called Jaysimha and Vikramsimha respectively. The story need not be retold as it is substantially the same as the original with only minor changes incorporated here and there. For instance, Cloten, who is the son of the Queen by a former husband, is transformed into a brother of hers, Raghupati, and this is done in order to suit the relationship in the new cultural setting. Again, the scene where ghosts appear before the sleeping Posthumous is dropped. Consequently, there is no message from Jove, nor is there a soothsayer. This seems to have been done in order to make the play seem realistic. But the most important innovation is to be seen in the importance accorded to the character of Tara (Imogen) from whom 
the play takes its name, whereas Shakespeare's play is named after the king, Cymbeline (Mahanta, 1985).

Anandachandra Barua's Kamata-Kuwari, written in 1931 and published in 1940, is based on the same theme, but it is more faithful to history than Nilambar. Taking the outline of the plot from Hiteswar Barbarua's account of the destruction of Kamatapur and Dr. Wade's An Account of Assam, the playwright demonstrates how ambition and thirst for revenge were at the root of the country's fall. However, external action dominates the play, resulting in the preponderance of intriguing situations. Kamata-Kuwari is more of a revenge play than a true historical tragedy. There is no villain of the type of Nanda, but murders, suicides, eating of one's own son's flesh and the like make it a play no less ghastly than Nilambar. The suspicion of Nilambar of KamataKuwari of his wife's fidelity after he has discovered underneath her pillow a love letter, supposedly written to Manohar, the minister's son, is obviously modeled on Othello. When Nilambar understands that the letter was not actually written by his wife but by one of her friends, he repents the wrong he has done to her, but it is too late to remedy the situation. The character of Bimala too seems to be fashioned after Shakespeare's Ophelia. When her lover, Manohar, is banished by the king, she becomes desperate, takes to incoherent crooning, and finally drowns herself. Harital, a comic figure who has been modeled on the Fool in Shakespeare. It is indeed the beastly natures of some of the major characters of the play that make it a horror play rather than a genuine tragedy.

Ashru-tirtha (1948) by Atulchandra Hazarika, a leading playwright, and teacher of literature, is a fairly competent rendering of King Lear. On Hazarika's competence as a translator, Pona Mahanta observes:

True that tragedy is less translatable than comedy and truer still that a great tragic drama like King Lear nearly defies translation. Yet it has been translated into so many different languages of the world, and our author, too, seems to have tried as best as he can to make it a really good work, despite the limitations that translation imposes (pp. 91-92).

The story is placed in ancient Assam with Pratapsimha (King Lear) as king of Kamrup, while the Dukes of Albany, Cornwall, and Burgandy, and the king of France become kings of Darrang, Kundil, Jayantapur and Kamatapur, respectively. The Earls of Kent and Gloucester become Abhaypuria and Jaypuria, representatives of the kings of Abhaypur and Jaypur, respectively. These changes had to be made because Earls and Dukes would be inconsistent with the political and social system of Assam. But what is important in King Lear is not so much the story as the expression of elemental passions and the ultimate purgation of emotions especially pity and fear. No translation, however good, can pretend to recreate a Shakespearean play, least of all King Lear. Mahanta continues, "What he [Hazarika] can best do is perhaps to take the outline of the story and put it in the way that he thinks best suits his language and the background that he adopts for his play" (Mahanta, 1985, p. 92). That is exactly what Hazarika does with a high degree of success.

Besides these, there have been other translations and adaptations such as Bhimdarpa (Macbeth), Ranjit (Othello) and Chandravir (Hamlet), but these plays, except the first two, have not seen the light of the day. Devananda Bharali's Bhimdarpa is about a king of the Kachari dynasty, who actually reigned in the seventeenth-century. He and his wife are presented as Indian versions of Macbeth and Lady Macbeth. A detailed discussion of this play is not possible as copies of the texts are not available now. According to Satyen Sarma, "Bhimdarpa is rather a play written in imitation of Macbeth than a translation of it" (Sarma, 2015, p. 9). In the words of Mahanta (1985), 
Lakshminath Bezbaroa attempted a very close rendering of Hamlet, but the work was never completed. This is perhaps the only attempt in Assamese at a closely literal translation of a Shakespearean drama, all the others being adaptations in some way or the other (p. 98).

A literal translation of a Shakespearean play into an Indian language - least of all Hamlet with all its cultural overtones and peculiarities of style and diction is a near impossibility. Therefore, Mahanta (1985) further states:

Bezbaroa seems to have realized it as he went on with his work, and so left it unfinished. Yet it shows Bezbaroa's love of Shakespeare whom he wanted to implant in the Assamese soil. When he found that direct implanting would neither be possible nor desirable, he took to writing plays in Assamese in imitation of Shakespeare (p. 98).

\section{Conclusion}

Tragic view of life, which was once a taboo on the traditional Indian stage, informs much of Assamese drama at present. It is only when the Assamese writers came into contact with western ideas in general and Shakespearean ideas in particular that they became aware of the human situation. In drama, this new note was struck as early as in 1857 , and now this is so much a part of these writers' sensibility that the tragic view of life has become inseparable from their own way of thinking. Other ideas and methods, which originated in the West, have also been assimilated likewise into the native milieu. Of all branches of literature, drama is certainly the most sensitive to social change. The Assamese drama of the pre-independence period owes for its growth much to its contact with the West, which has also been largely responsible for the remarkable changes that our society, in all its aspects, has undergone during the period.

It has been discussed at some length in the foregoing pages that Shakespearean influence on Assamese drama has been continuously operating in various ways. Nevertheless, there might come a time when it would be difficult to clear off this indebtedness to the West in general and Shakespeare in particular and the writers might find their inspiration entirely within their own social context. It is, therefore, appropriate to draw the following conclusions: The modern Assamese dramatic production has been indubitably influenced by Shakespearean plays. Most of the modern Assamese plays have evolved as a result of their writers' interaction with the West, especially with the dramas of Shakespeare. However, the subject matter of modern Assamese dramas is indigenous despite the fact that characterization, dialogue, style, and technique are chiefly based on the dramatic style of Western model with the echoes of Shakespeare.

\section{References}

Barua, B.K. (2015), History of Assamese Literature, Sahitya Academy, New Delhi

Bradley, A.C. (1991), Shakespearean Tragedy, Penguin Classics, London

Carlton, H.B. (2010), Shakespearean Tragedy, Cambridge University Press, UK.

Chaliha, P. (1946), Amar-Lila, State Central Library, Shillong

Chetia, J. (1979), Asamiya Adhunik Natakar Oprat Pashchatya Natakar Prabhab (Western Influence on Modern Assamese Drama), Rangamancha, Jorhat 
9 | Shakespeare's Influence on Pre-Independence Assamese Tragedy: a Historical Perspective

Ghosh, A. K. (1966), Bangla Nataker Itihas, General Printers and Publishers Ltd., Calcutta

Gogoi, B. (2017), Translation in Assamese: A Brief Account, History of Translation in India, National Translation Mission, CIIL, Mysuru

Hazarika, A. (1950), Banij Kowar, Lawyers' Book Stall, Guwahati

Hazarika, A. (1967), Manchalekha, Junaki Prakashan, Gauhati

Jana, J. (2015), Shakespeare in Comparative Discourse and Influence Studies in the Assamese Language Print Media, Space and Culture, India, 2(4), pp. 3-16, ACCB Publishing, England

Kakati, B. (2007), Purani Asamiya Sahitya, Asama Prakasana Parishada, Guwahati

Mack, M. (1994), Everybody's Shakespeare, University of Nebraska Press, Lincoln

Mahanta, P. (1985), Western Influence on Modern Assamese Drama, Mittal Publications, Delhi

Misra, T. (2007), Ramnabami-Natak: The Story of Ram and Nabami, Oxford University Press, Delhi

Pathak, D. (2008), Asomiya Natakat Shakespeare or Prabhab, Asomiya Natak: Parampara Aru Paribartan, ed. Dr. Parmananda Rajbonshi, Chandraprakash, Guwahati

Sarma, S. (1973), Asamiya Natya Sahitya, New Book Stall, Guwahati

Sarma, S. (2015), Asamiya Sahityar Samikshatmak Itivritta, Soumar Prakash, Guwahati

Sarma, S. (1964), Sahityar Abhas, Dutta Baruah \& Co., Guwahati

Sen, S. (1955), History of Brajabuli Literature, University of Calcutta, Calcutta

Shakespeare in India (2019, April 20), Internet Shakespeare Editions. Retrieved from http://internetshakespeare.uvic.ca/Library/Criticism/shakespearein/indial 